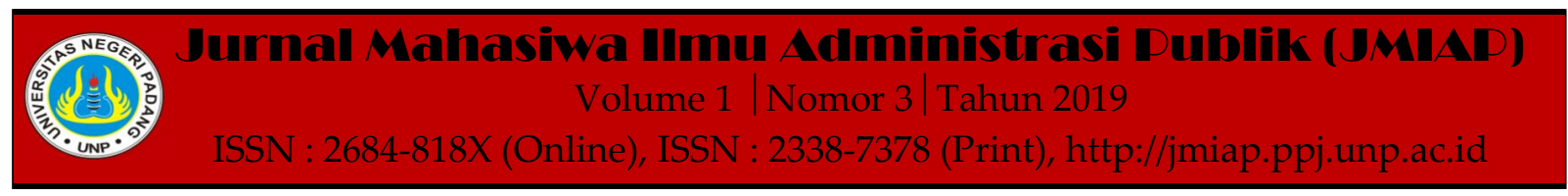

\title{
PENGARUH KECERDASAN EMOSIONAL TERHADAP KINERJA PEGAWAI DI ORGANISASI PERANGKAT DAERAH
}

\author{
Frans Sanjaya ${ }^{1(a)}$ \\ ${ }^{1}$ Magister Administrasi Publik, Fakultas Ilmu Sosial, Universitas Negeri Padang \\ a)sanjayafrans92@yahoo.com
}

\begin{abstract}
This study aims to determine the contribution of emotional intelligence on the performance of employees in the District Device Organization of Tanah Datar Regency. The background of this study was the finding of problems in the emotional intelligence of employees that were not good in the District Device Organization of Tanah Datar Regency. This type of research is a quantitative research whose population is all civil servants in the area of the regional apparatus of Tanah Datar regency totaling 1.596 people. The sample in this study consisted of 320 respondents who were determined using the Slovin formula with an error rate of 5\% and sampling was done through Multi Stage Random Sampling technique. Data collection in this study uses a questionnaire with Likert scale measurement. Data of this study were analyzed with linear regression test. The results showed that there was a contribution between emotional intelligence to employee performance by $22,9 \%$. So it can be concluded that emotional intelligence contribute significantly to employee performance.
\end{abstract}

Keywords : Emotional Intelligence, Performance

Corresponding author. Email. sanjayafrans92@yahoo.com

How to cite this article. Sanjaya. F. (2019). Pengaruh Kecerdasan Emosional Terhadap Kinerja Pegawai di Organisasi Perangkat Daerah. Jurnal Mahasiwa Ilmu Administrasi Publik (JMIAP) Jurusan Ilmu Administrasi Negara Fakultas Ilmu Sosial Universitas Negeri Padang, Volume 1 (3), Hal. 91-98. http://jmiap.ppj.unp.ac.id

ISSN : 2684-818X (Online), ISSN : 2338-7378 (Print)

Copyright $\bigcirc 2019$. Published by Pusat Kajian-Pemberdayaan dan Pelayanan Masyarakat (PK-P2M) FIS UNP Padang 


\section{PENDAHULUAN}

Seseorang yang memiliki kecerdasan emosional yang meliputi kesadaran diri yang baik akan mampu membuat keputusan yang tegas dan tepat walaupun di hadapkan pada tuntutan kerja yang berat dan tekanan di lingkungan kerja. Seseorang yang memiliki kecerdasan emosional akan dapat menunjukan integritasnya, mampu berpikir jernih dalam keadaan tertekan, bertindak sesuai etika, berpegang pada prinsip, dan memiliki dorongan untuk berprestasi. Kecerdasan emosional akan membuat individu menggunakan emosi secara efektif untuk mencapai tujuan dengan tepat, membangun hubungan kerja yang produktif dan meraih prestasi ditempat kerja.

Goleman (1999: 57) menyebutkan lima komponen kecerdasan emosional yaitu: (a) mengenali emosi diri, (b) mengelola emosi, (c) memotivasi diri sendiri, (d) mengenali emosi orang lain, dan (e) membina hubungan dengan orang lain. Kemampuan mengenali emosi diri sendiri akan membuat pegawai memahami apa yang sedang dirasakannya. Sedangkan mengelola emosi bertujuan agar pegawai dapat mengontrol emosinya. Memotivasi diri sendiri yaitu kemampuan untuk membangkitkan semangat kerja yang tinggi pada diri pegawai agar dapat mencapai tujuan organisasi. Mengenali emosi orang lain yaitu kemampuan pegawai dalam mengenali emosi orang lain, dan membina hubungan yaitu kemampuan dalam berinteraksi dengan orang lain.

Ely Susanto dalam Pramusinto (2009:325) menyatakan kecerdasan emosional birokrat bisa meningkatkan kinerja pelayanan kepada masyarakat karena : (1) dengan memahami kondisi emosi dirinya sendiri dan kondisi emosi masyarakat yang dilayani, seorang birokrat akan mampu menjaga hubungan baik dengan masyarakat yang dilayani, (2) dengan kecerdasan emosional seorang birokrat akan mampu mengontrol dan mengelola stress sehingga dampaknya tidak sampai kepada masyarakat yang dilayani, (3) kecerdasan emosional akan membantu seorang birokrat untuk berkomunikasi dengan baik dan lancar.

Dinas Kependudukan dan Pencatatan Sipil merupakan salah satu Organisasi Perangkat Daerah (OPD) di Kabupaten Tanah Datar. Sebagai pelayan masyarakat, pegawai yang bekerja dilingkungan Organisasi Perangkat Daerah (OPD) harus memberikan pelayanan yang terbaik kepada masyarakat karena indikator kinerjanya salah salah satunya ditentukan oleh seberapa puas masyarakat mendapat pelayanan dari pegawai. Disisi lain banyaknya masyarakat yang membutuhkan layanan yang cepat membuat pegawai harus bertindak cepat. Ketidakmampuan memenuhi harapan masyarakat akan berujung pada caci maki dan sumpah serapah. Namun pada kenyataannya masih ada pegawai yang bermalas-malasan dalam bekerja.

Selanjutnya pegawai di Dinas Kependudukan dan Pencatatan Sipil Kabupaten Tanah Datar juga masih suka menunda-nunda pekerjaan yang membuat menumpuknya pekerjaan. Dan biasanya pegawai akan mengerjakan pekerjaan yang tertunda apabila sudah dekat dengan batas waktu yang ditentukan, yang membuat pegawai terpaksa lembur dan memberi dampak stresnya pegawai dalam penyelesaian pekerjaannya tersebut.

Di samping itu melalui pengamatan awal penulis, juga masih ditemui keluhan masyarakat terkait dengan tidak ramahnya pegawai dalam memberikan pelayanan kepada masyarakat. Masih adanya perbedaan pelayanan terhadap masyarakat dengan orang yang kenal dengan pegawai di lingkungan Dinas Kependudukan dan Pencatatan Sipil kabupaten Tanah Datar, hal ini ditunjukan dengan masih adanya pembuatan dokumen oleh orang yang kenal dengan pegawai tanpa melalui prosedur yang telah ditetapkan. Untuk sesama 
pegawai juga masih ditemukan ketidakakuran antara pegawai, hal ini dapat dilihat dari masih adanya pegawai yang saling menjelek-jelekan pegawai lainnya.

Permasalahan lain juga muncul dengan kurangnya kerja sama antara pegawai yang tergambar dari tersendatnya pelayanan apabila ada pegawai yang mengikuti kegiatan dinas luar dan pegawai lain tidak mau mengisi posisi pegawai tersebut dalam melakukan pelayanan kepada masyarakat. Hal ini juga berakibat protes masyarakat karena lambatnya pelayanan yang pada ujungnya membuat adanya perdebatan antara pegawai Disdukcapil Kabupaten Tanah Datar dan masyarakat.

Selain itu, masih ada masih banyaknya fenomena oknum pemerintah yang bersikap dan berpola-laku arogan. Salah satunya kasusnya yaitu masalah dugaan sikap arogan dan pelecehan terhadap wartawan yang dilakukan oleh oknum Pegawai Negeri Sipil (PNS) berinisial "MD" yang bertugas di instansi Penanaman Modal Pelayanan Satu Pintu dan Tenaga Kerja (PMPTSP-Naker) Kab. Tanah Datar. (Sumbar Kabar Daerah, 2018).

Berdasarkan gejala yang telah dijelaskan di atas, maka dapat disimpulkan bahwa banyak faktor yang mempengaruhi kinerja pegawai mulai dari disiplin pegawai, sikap pegawai termasuk kecerdasan emosional dan kecerdasan sosial pegawai. Berdasarkan dari permasalahan di atas maka ada beberapa masalah yang berkaitan dengan faktor-faktor kecerdasan emosional pegawai seperti kurangnya motivasi pegawai dalam bekerja dan masih ada pegawai yang kurang mampu mengelola emosinya yang terindikasi melalui masih adanya perdebatan antara pegawai dan masyarakat dan pegawai masih belum mampu mengelola stress yang disebabkan oleh tuntutan pekerjaan.

Hal lain yang menjadi dasar peneliti untuk melakukan penelitian ini dikarenakan masih minim kajian-kajian tentang dampak kecerdasan emosional di organisasi publik. Meskipun kajian-kajian ilmiah sudah banyak memberikan bukti bahwa kecerdasan emosional dan kecerdasan sosial adalah salah satu faktor penting bagi kinerja seseorang atau tim, namun hal tersebut belum banyak dibuktikan di organisasi publik karena kebanyakan kajian-kajian tersebut menggunakan setting organisasi swasta. Menurut Ely Susanto di dalam Pramusinto (2009:323) ada beberapa alasan kenapa kajian-kajian kecerdasan emosional dan kecerdasan sosial menarik untuk dilakukan di organisasi publik. Pertama, pengukuran kinerja organisasi swasta lebih jelas dan mudah di pahami sedang, pengukuran kinerja sektor publik lebih sulit dioperasionalkan.

Kedua, dalam pengambilan keputusan organisasi publik melibatkan lebih banyak kelompok kepentingan yang beragam. Ketiga, semua kegiatan dan kebijakan yang dibuat oleh organisasi publik selalu dimonitor oleh media massa dan masyarakat sehingga prinsip kehati-hatian menjadi prioritas sedang sektor swasta relatif tidak mengalami hal tersebut. perbedaan- perbedaan keadaan antara organisasi publik dan swasta tersebut akan membawa pengaruh yang berbeda terhadap perilaku setiap pegawainya, yang nanti juga akan berpengaruh terhadap tingkat stres dan masalah psikologis lainnya sehingga kajiankajian tentang kecerdasan emosional dan kecerdasan sosial di organisasi publik sangat menarik untuk dilakukan. Sehingga penulis tertarik untuk melakukan penelitian di Organisasi Perangkat Daerah (OPD) Kabupaten Tanah Datar dengan judul "Pengaruh Kecerdasan Emosional Terhadap Kinerja Pegawai Di Organisasi Perangkat Daerah Kabupaten Tanah Datar".

\section{TINJAUAN PUSTAKA}

\section{Konsep Kinerja}

Marwansyah

(2014:228)

mengemukakan kinerja adalah pencapaian atau prestasi seseorang berkenaan dengan 
tugas-tugas yang di bebankan kepadanya. Kinerja dapat pula di pandang sebagai perpaduan dari hasil kerja (apa yang harus dicapai oleh seseorang) dan kompetensi (bagaimana seseorang mencapainya). Colquitt, Lepine, dan Wesson dalam Wibowo (2016:2) menyatakan kinerja adalah nilai serangkaian perilaku pekerja yang memberikan kontribusi, baik secara positif maupun negatif, pada penyelesaian tujuan organisasi. Selanjutnya Cascio dalam Wibowo (2016:2) menjelaskan kinerja sebagai cara untuk memastikan bahwa pekerja individual atau tim tahu apa yang diharapkan dari mereka dan mereka tetap fokus pada kinerja efektif dengan memberikan perhatian pada tujuan, ukuran dan penilaian.

Selain itu, Mangkunegara (2009:67) mengatakan bahwa kinerja merupakan hasil kerja secara kualitas dan kuantitas yang dicapai oleh seseorang dalam melaksakan fungsinya sesuai dengan tanggung jawab yang diberikan kepadanya. Selain itu Miner dalam Sutrisno (2010:170) menjelaskan kinerja adalah bagaimana seseorang diharapkan dapat berfungsi dan berperilaku sesuai dengan tugas yang telah dibebankan kepadanya.

Edison (2016:190), mengemukakan kinerja adalah hasil dari suatu proses yang mengacu dan diukur selama periode waktu tertentu berdasarkan ketentuan atau kesepakatan yang telah ditetapkan sebelumnya. Sedangkan Sinambela (2006:136) mendefinisikan kinerja pegawai sebagai kemampuan pegawai dalam melakukan sesuatu dengan keahlian tertentu. Selain itu Robbins (2006:439) menyatakan kinerja adalah hasil evaluasi terhadap pekerjaan yang dilakukan oleh pegawai dibandingkan kriteria yang telah ditetapkan sebelumnya.

\section{Kecerdasan Emosional}

Marwansyah (2014:5) mengemukakan kecerdasan emosional merujuk kepada keterampilan, kapabilitas, dan kompetensi non-kognitif yang mempengaruhi kemampuan seseorang untuk berhasil dalam menghadapi tuntutan dan tekanan lingkungan. Sedangkan Goleman dalam Marwansyah (2014:5) menyatakan kecerdasan emosional adalah kapasitas untuk memahami emosi kita dan mengelolanya secara efektif dan untuk memahami dan efektif mengelola emosi orang lain. Senada dengan itu , Purba dalam Rahmasari (2016:6) mengartikan kecerdasan emosi sebagai kemampuan di bidang emosi yaitu kesanggupan menghadapi frustasi, kemampuan mengendalikan emosi, semangat optimisme, dan kemampuan menjalin hubungan dengan orang lain atau empati.

Robert K. Cooper dan Ayman Sawaf berpendapat bahwa kecerdasan emosional adalah kemampuan mengindra, memahami, dan dengan efektif menerapkan kekuatan dan ketajaman emosi sebagai sumber energi, informasi dan pengaruh dalam Rosalina (2008:198). Patton dalam Setyaningrum (2016:213) mendefinisikan kecerdasan emosional yaitu keterampilan menggunakan emosi secara efektif untuk mencapai sebuah tujuan dan mampu membangun hubungan yang baik serta mampu meraih kesuksesan ditempat kerja.

Ciri-ciri kecerdasan emosional meliputi kemampuan untuk memotivasi diri sendiri dan bertahan ketika menghadapi sebuah masalah yang membuat frustasi, mengendalikan dorongan hati dan tidak melebih-lebihkan perasaan ketika sedang bergembira, mengatur suasana hati dan menjaga agar beban pikiran ketika menumpuk tidak melumpuhkan kemampuan dalam berpikir, berempati, dan berdoa.

Dari penjelasan diatas dapat diambil kesimpulan bahwa kecerdasan emosional adalah kemampuan untuk mengenali perasaan orang lain dan diri sendiri serta kemampuan memantau perasaan orang lain dan diri sendiri, dan juga memilah-milah 
Frans Sanjaya | Pengaruh Kecerdasan Emosional Terhadap Kinerja Pegawai di Organisasi Perangkat Daerah

semuanya agar dapat membimbing pikiran dan tindakan.

\section{METODE PENELITIAN}

Penelitian ini adalah penelitian kuantitatif. Populasi dalam penelitian ini adalah seluruh pegawai negeri sipil yang berada dalam lingkup Organisasi Perangkat Daerah (OPD) Kabupaten Tanah Datar yang berjumlah 1.596 orang. Sampel dalam penelitian ini terdiri dari 320 pegawai negeri sipil yang ditentukan dengan menggunakan rumus Slovin dengan tingkat kesalahan $5 \%$ dan teknik pengambilan sampel menggunakan teknik Multi Stage Random Sampling. Teknik pengumpulan data dalam penelitian ini menggunakan angket. Teknik analisis data yang digunakan adalah regresi linear sederhana.

HASIL DAN PEMBAHASAN

\section{Tabel 1. Hasil Pengaruh (R) Variabel Kecerdasan Emosional Terhadap Kinerja Pegawai di Organisasi Perangkat Daerah (OPD) Kabupaten Tanah Datar}

\section{Model Summary}

\begin{tabular}{|c|c|c|c|c|c|}
\hline Model & $\mathrm{R}$ & R Square & $\begin{array}{l}\text { Adjusted R } \\
\text { Square }\end{array}$ & $\begin{array}{l}\text { Std. Error of the } \\
\text { Estimate }\end{array}$ & $\begin{array}{l}\text { Durbin- } \\
\text { Watson }\end{array}$ \\
\hline 1 & $.481^{\mathrm{a}}$ & .231 & .229 & .491 & 1.828 \\
\hline
\end{tabular}
a. Predictors: (Constant), Kinerja
b. Dependent Variable: Kecerdasan Emosional

Berdasarkan tabel di atas dapat di pahami bahwa, nilai Adjusted $R$ Square sebesar 0,229, yang artinya pengaruh

kecerdasan emosional terhadap kinerja pegawai sebesar 22,9\%. Sisanya dipengaruhi oleh variabel lain yang tidak diteliti dalam penelitian ini.

Tabel 2. Hasil Uji Anova (F) Variabel Kecerdasan Emosional terhadap Kinerja Pegawai

\begin{tabular}{|c|c|c|c|c|c|c|}
\hline \multicolumn{7}{|c|}{ ANOVA $^{b}$} \\
\hline Model & & $\begin{array}{l}\text { Sum of } \\
\text { Squares }\end{array}$ & $\mathrm{df}$ & $\begin{array}{l}\text { Mean } \\
\text { Square }\end{array}$ & $\mathrm{F}$ & Sig. \\
\hline \multirow[t]{3}{*}{1} & Regression & 23.016 & 1 & 23.016 & 95.630 & $.000^{\mathrm{a}}$ \\
\hline & Residual & 76.534 & 318 & .241 & & \\
\hline & Total & 99.550 & 319 & & & \\
\hline
\end{tabular}
a. Predictors: (Constant), Kinerja
b. Dependent Variable: Kecerdasan Emosional 
Berdasarkan tabel di atas, nilai signifikansi sebesar 0.000, karena signifikansi uji nilainya lebih kecil dari 0,05 maka dapat disimpulkan bahwa variabel kecerdasan emosional berpengaruh terhadap kinerja pegawai.

\section{Tabel 3. Hasil Uji T Variabel Kecerdasan Emosional terhadap Kinerja Pegawai}

\begin{tabular}{|c|c|c|c|c|c|c|}
\hline \multicolumn{7}{|c|}{ Coefficients ${ }^{a}$} \\
\hline \multirow[b]{2}{*}{ Model } & & \multicolumn{2}{|c|}{$\begin{array}{c}\text { Unstandardized } \\
\text { Coefficients }\end{array}$} & \multirow{2}{*}{$\begin{array}{c}\begin{array}{c}\text { Standardized } \\
\text { Coefficients }\end{array} \\
\text { Beta }\end{array}$} & \multirow[b]{2}{*}{$\mathrm{t}$} & \multirow[b]{2}{*}{ Sig. } \\
\hline & & $\mathrm{B}$ & Std. Error & & & \\
\hline \multirow[t]{2}{*}{1} & (Constant) & 1.215 & .226 & & 5.365 & .000 \\
\hline & Kinerja & .112 & .012 & .481 & 9.779 & .000 \\
\hline
\end{tabular}

a. Dependent Variable: Kecerdasan Emosional

Berdasarkan tabel di atas, nilai signifikansi sebesar 0,000 lebih kecil dari 0,05 sehingga dapat disimpulkan bahwa Ho ditolak dan Ha diterima yang berarti terdapat pengaruh variabel kecerdasan emosional terhadap kinerja pegawai di Organisasi Perangkat Daerah (OPD) Kabupaten Tanah Datar.

\section{Kontribusi Kecerdasan Emosional Terhadap Kinerja Pegawai di Organisasi Perangkat Daerah (OPD) Kabupaten Tanah Datar}

Berdasarkan hal uji regresi secara parsial sub variabel Kecerdasan Emosional (X1) terhadap variabel kinerja pegawai (Y) di Organisasi Perangkat Daerah (OPD) Kabupaten Tanah Datar didapatkan hasil bahwa, nilai Adjusted $R$ Square sebesar 0,229 , yang artinya pengaruh kecerdasan emosional terhadap kinerja pegawai sebesar $22,9 \%$. Sisanya sebesar dipengaruhi oleh variabel lain yang tidak diteliti dalam penelitian ini.

Selanjutnya berdasarkan hasil uji annova (F) didapatkan nilai signifikansi sebesar 0.000 , karena signifikansi uji nilainya lebih kecil dari 0,05 maka dapat disimpulkan bahwa variabel kecerdasan emosional berpengaruh terhadap kinerja pegawai.
Begitu juga halnya hail uji t didapatkan nilai signifikansi sebesar 0,000 lebih kecil dari 0,05 sehingga dapat disimpulkan bahwa Ho ditolak dan Ha diterima yang berarti terdapat pengaruh varaiabel kecerdasan emosional dan kecerdasan sosial terhadap kinerja pegawai di Organisasi Perangkat Daerah (OPD) Kabupaten Tanah Datar.

Marwansyah (2014:5) mengemukakan kecerdasan emosional merujuk kepada keterampilan, kapabilitas, dan kompetensi non-kognitif yang mempengaruhi kemampuan seseorang untuk berhasil dalam menghadapi tuntutan dan tekanan lingkungan. Sedangkan Goleman dalam Marwansyah (2014:5) menyatakan kecerdasan emosional adalah kapasitas untuk memahami emosi kita dan mengelolanya secara efektif dan untuk memahami dan efektif mengelola emosi orang lain. Senada dengan itu, Purba dalam Rahmasari (2016:6) mengartikan kecerdasan emosi sebagai kemampuan di bidang emosi yaitu kesanggupan menghadapi frustasi, kemampuan mengendalikan emosi, semangat optimisme, dan kemampuan menjalin hubungan dengan orang lain atau empati. 
Terlihat pada penelitian adanya kontribusi signifikan antara kecerdasan emosional terhadap kinerja pegawai. Hal ini dapat disebabkan karena kecerdasan emosional merujuk kepada keterampilan, kapabilitas, dan kompetensi non-kognitif yang mempengaruhi kemampuan seseorang untuk berhasil dalam menghadapi tuntutan dan tekanan lingkungan.

Sesuai dengan pendapat Setyaningrum (2016:214) mengemukan hubungan atau pengaruh lima komponen kecerdasan emosional terhadap kinerja karyawan, yaitu: 1) Kesadaran diri, dimana dengan kesadaran diri yang baik membuat seorang karyawan dapat tampil dengan keyakinan diri, sehingga dapat berbuat tegas dan mampu membuat keputusan yang baik dalam keadaan tidak pasti dan tertekan. 2) Pengaturan diri, dimana seseorang karyawan yang mampu mengatur emosi diri yang baik akan memiliki rasa tanggung jawab atas kinerjanya pribadi dan mempunyai kemampuan beradaptasi dalam menghadapi berbagai perubahan. 3) Motivasi, dimana adanya kemampuan untuk memotivasi diri sendiri akan membuat karyawan menjadi lebih semangat dalam bekerja, sehingga kinerjanya akan meningkat. 4) Empati, dimana adanya kemampuan berempati membuat seseorang menjadi mudah diterima banyak orang dan merasa diharga, begitu pula hal yang sama dirasakan orang lain yang merasa dirinya dihargai dengan pemikiran yang mempunyai perbedaan sudut pandang dan 5) Keterampilan social, dimana keterampilan sosial yaitu kemampuan until menangani emosi dengan baik dan berinteraksi dengan lancar ketika berhubungan dengan orang lain, mempengaruhi dan memimpin orang lain, dapat menyelesaikan perselisihan dan untuk bekerja sama dalam tim.

\section{PENUTUP}

Kontribusi kecerdasan emosional terhadap kinerja pegawai memiliki nilai Adjust $R$ Square 0,229 sehingga kontribusi kecerdasan emosional terhadap kinerja pegawai sebesar $22,9 \%$. Hal ini berarti bahwa kecerdasan emosional seorang karyawan sangat dibutuhkan dalam menciptakan kinerja individu yang tinggi. Dalam penelitian ini kecerdasan emosional memiliki pengaruh yang signifikan terhadap kinerja pegawai. Secara parsial nilai signifikansi variabel lebih kecil dari 0,05, maka Ho ditolak dan Ha diterima.

\section{DAFTAR KEPUSTAKAAN}

Edison, Emron, dkk. 2016. Manajemen Sumber Daya Manusia. Bandung: Alfabeta.

Goleman, Daniel. 1999. Kecerdasan Emosional. Jakarta: PT. Gramedia Pustaka Utama.

\section{Social Intelligence.}

Jakarta: PT. Gramedia Pustaka Utama.

Hasibuan, Malayu S.P. 2012. Manajemen Sumber Daya Manusia. Jakarta: PT. Bumi Aksara.

Marwansyah. 2012. Manajemen Sumber Daya Manusia. Bandung: Alfabeta. . 2014. Manajemen Sumber Daya Manusia. Bandung: Alfabeta.

Mangkunegara, Anwar Prabu. 2009. Evaluasi Kinerja SDM. Bandung: PT. Refika Aditama.

. 2011. Manajemen Sumber Daya Manusia Perusahaan. Bandung: PT.Remaja Rosdakarya.

Pramusinto, Agus. 2009. Reformasi Birokrasi, Kepemimpinan, dan Pelayanan Publik. Yogyakarta: Gava Media.

Rahmasari, Lisda. 2012. "Pengaruh Kecerdasan Intelektual, Kecerdasan Emosi, dan Kecerdasan Spritual Terhadap Kinerja Karyawan". Majalah Ilmiah Informatika. Volume 3, No 1, 2012. 
Rosalina, Willy Lutfiana. 2008. "Pengaruh Kecerdasan Emosional Perawat Terhadap Perilaku Melayani Konsumen dan Kinerja Perawat RSUD Kabupaten Indramayu”. Jurnal Ekonomi dan Bisnis. Volume 2, No 3, 2008 .

Rosyad, Soleh,. Arifin, M. Zaenal., \& Harismasakti, Eris. 2014. "Pengaruh Keecerdasan Emosional Terhadap Kinerja Pegawai Perguruan Tinggi La Tansa Mashiro di Rangkasbitung". EJurnal Management. Volume 3, No 3, 2014.

Sinambela, Lijan Poltak. 2006. Reformasi Pelayanan Publik. Jakarta: Bumi Aksara.

Santoso, Rudi., Candraningrat., \& Binawati, Lilis. 2017. " Elemen Kecerdasan Wirausaha Untuk Meningkatkan Kinerja Industri Kecil dan Menengah (IKM) Surabaya”. Jurnal Unesa. Volume 10, No 1, 2017.

Setyaningrum, Rani., Utami, Hamidah Nayati,. \& Ruhana, Ika. 2016. "Pengaruh Kecerdasan Emosional Terhadap Kinerja”. Jurnal Administrasi Bisnis. Volume 36, No 1, 2016.

Sutrisno, Edy. 2009. Manajemen Sumber Daya Manusia. Jakarta: Kencana Prenada Media Grup.

Wibowo. 2016. Manajemen Kinerja. Jakarta: PT. Raja Grafindo Persada.

https://sumbar.kabardaerah.com/lecehkanwartawan-ketum-ppwi-sesalkan-sikap arogan-oknum-pns-tanah-datar/. 